Kredo 4 (2020)
KREDO: Jurnal Ilmiah Bahasa dan Sastra
Terakreditasi Sinta 4 berdasarkan Keputusan Direktorat
Jenderal Penguatan Riset dan Pengembangan,
Kementerian Riset, Teknologi dan Pendidikan Tinggi
Republik Indonesia
Nomor: 23/E/KPT/2019. 08 Agustus 2019
https://jurnal.umk.ac.id/index.php/kredo/index

\title{
PROSES MORFOLOGI DALAM PENAMAAN TAMAN TEMATIK DI KOTA BANDUNG
}

\author{
Ponia Mega Septiana \\ poniamega93@gmail.com
}

\begin{abstract}
Sekolah Tinggi Ilmu Ekonomi STAN Indonesia Mandiri
Bandung, Indonesia
\end{abstract}

Info Artikel
Sejarah Artike
Diterima
15 Juli 2019
Disetujui
9 Juni 2020
Dipublikasikan
28 Oktober 2020

\section{Keywords}

morphological process, naming park of Bandung, word formation.

Kata Kunci proses morfologis, proses pembentukan kata, proses penamaan taman di Bandung.

\section{Abstract}

The reign of the mayor, Mr. Ridwan Kamil, Bandung had twenty-four thematic parks consisting of a new park and a recap of the previous park. The park had a unique name and its history of the name. The uniqueness of this name made the researcher want to analyze the naming process using a morphological process, namely word-formation. This research focuses on analyzing the morphological process in thematic park naming using $O^{\prime} G r a d y$ (2016) theory. The main theory is used word-formation. Word formation is a process of forming new words using several types, such as blending which is a combination of two or more words into one, borrowing is the use of words from other languages without changing the meaning of writing, coined namely the formation of words based on the background of a word, and compounding where the merging of two words or more. Qualitative and descriptive methods are used in this research. The methods aim to create a description of situations and events by using the document analysis technique. As the result, naming parks in Bandung using a morphological process proves that there are four processes found in the use of naming parks in Bandung. There are blending, borrowing, coined word, and compounding. The dominant process is used in the naming park that is the borrowing process.

Abstrak
Masa pemerintahan walikota Bapak Ridawan Kamil, Bandung memiliki dua puluh
empat taman tematik yang terdiri dari taman baru dan rekapitulasi dari taman sebelumnya. Taman
tersebut memiliki nama yang unik dan sejarah tersendiri dari masing-masing nama. Keunikan
nama tersebut membuat peneliti ingin menganalisis proses penamaan dengan menggunakan proses
morfologi yaitu word formation. Fokus utama dalam penelitian ini adalah menganalisis proses
morfologi dalam penamaan taman tematik menggunakan teori dari O'Grady (2016). Teori utama
yang digunakan adalan teori pembentukan kata (word formation). Pembentukan kata adalah suatu
proses pembentukan kata baru dengan berbagai macam proses, seperti blending yang dimana
kombinasi dari dua kata atau lebih menjadi satu, borrowing adalah penggunaan kata dari bahasa
lain tanpa merubah arti ataupun penulisan, coined yaitu terbentuknya kata berdasarkan
latarbelakang sebuah kata, serta compounding dimana terjadinya pengabungan dua kata atau
lebih. Metode kualitatif dan metode deskriptif digunakan dalam penelitian ini, metode tersebut
bertujuan untuk membuat suatu gambaran mengenai situasi atau kejadian dengan menggunakan
teknik analisis dokumen. Hasil dari penelitian tentang analisis penamaan taman tematik
menggunakan proses morfologi membuktikan bahwa ada empat proses morfologi ditemukan
dalam nama - nama taman di Bandung yaitu: blending, borrowing, coined word serta
compounding. Proses yang dominan digunakan dalam penamaan adalah proses borrowing.

\section{PENDAHULUAN}

Kota Bandung yang dikenal dengan Kota kembang merupakan Kota dengan hampir tiga juta jiwa. Masa pemerintahan Bapak Ridwan Kamil menjadi Walikota Bandung, Kota Bandung berubah menjadi kota yang semakin indah serta menjadikannya kota yang nyaman bagi kaum muda maupun semua kalangan dengan tampilan tatakota yang baru, serta membangun beberapa taman kota.

Sejak pemerintahan Walikota Ridwan Kamil, yang sekarang menjadi gubernur Jawa Barat periode 2018. 


Kredo 4 (2020)
KREDO: Jurnal Ilmiah Bahasa dan Sastra
Terakreditasi Sinta 4 berdasarkan Keputusan Direktorat
Jenderal Penguatan Riset dan Pengembangan,
Kementerian Riset, Teknologi dan Pendidikan Tinggi
Republik Indonesia
Nomor: 23/E/KPT/2019. 08 Agustus 2019
https://jurnal.umk.ac.id/index.php/kredo/index

Bandung sedikitnya memiliki 24 Taman Kota yang menjadikan Taman tersebut menjadi tempat favorit wisatawan di Kota Bandung. Taman - Taman ini kebanyakan merupakan hasil dari revitalisasi dari Taman - Taman sebelumnya agar menjadi lebih indah dan memberikan daya tarik bagi wisatawan lokal maupun internasional.

Tanam Kota merupakan Taman yang berada pada lingkungan pusat perkotaan yang mana bertujuan memberikan suasana nyaman dan dapat dinikmati oleh semua kalangan masyarakat. Menurut Irwan (2007) taman kota merupakan ruang terbuka hijau yang mempunyai fungsi utama untuk keindahan dan interaksi social, seperti halnya di Kota Bandung, Tanam Kota disebut dengan Taman tematik karena setiap Taman memiliki tema dan Nama- Nama yang unik. Taman tematik di Bandung yang terkenal dan menjadi tempat favorit seperti: Taman Vanda, Taman Tepian Anak Sungai Cikapayang, Taman Pustaka Bunga Cilaki, Taman Fotografi, Taman Jomblo, Taman Film, Taman Musik, Taman Lansia, Taman Skateboard, Taman Superhero dan masih banyak lagi.

Ada banyak nama tempat yang akhirnya kita tahu nama tersebut memiliki arti dan dapat dianalisis secara ilmiah. Kasiahe, dkk (2019) meneliti proses morfologis dalam penamaan marga Etnis Sangihe berdasarkan bentuk lingualnya untuk melihat bahwa didalam sebuah nama terjadi proses morfologisnya. Hasil penelitiannya ditemukan bahwa sebuha afiks yang sama dapat menghasilkan makna gramatikal yang berbeda tergantung kelas katanya.

\section{2 | Jurnal Kredo}

Vol. 4 No. 1 Oktober 2020
Sujatna (2016) yang mana menceritakan beberapa nama tempat destinasi wisata di Jawa Barat dengan menggunakan proses morfologi. Salah satu tempat terkenal di Jawa Barat yaitu Situ Patenggang atau Situ Pateangan. Nama tempat tersebut berasal dari bahasa Sunda "Pateangan - teangan" yang artinya saling mencari satu sama lain, dan "situ" artinya danau. Maka, Situ Patenggang atau Situ Pateangan terbentuk dari proses morfologi Blending yang mana sebuah penggabungan dua kata menjadi satu dengan arti yang baru.

Pemilihan nama yang digunakan alat penamaan suatu tempat itu pun sangat penting. Berdasarkan Rahma (2020) nama dinilai hanya memiliki referen oleh sebagian ahli. Namun, sebagian lainnya menentang dan menyebutkan bahwa makna nama lebih dari sebuah referen. Begitu pula menurut Sibarani (2006) dalam Santosa (2020) proses penamaan dibagi menjadi 2 yaitu 1) common meaning atau proses penamaan untuk benda umum sehingga membentuk kata - kata benda umum. 2) proper naming digunakan untuk namanama orang atau khusus.

Dilihat dari penelitian sebelumnya, pertama, mengaitkan proses morfologi dengan makna gramatikal dalam penamaan Etnis Sangihe dan penelitian yang kedua menggunakan proses pembentukan kata baru.

Berdasarkan latarbelakang pada penelitian ini, penulis ingin mendeskripsikan dan menganalisis bentuk proses morfologi dan makna nama yang dihasilkan dari proses morfologi dalam penamaan taman tematik di kota Bandung. 


Kredo 4 (2020)
KREDO: Jurnal Ilmiah Bahasa dan Sastra
Terakreditasi Sinta 4 berdasarkan Keputusan Direktorat
Jenderal Penguatan Riset dan Pengembangan,
Kementerian Riset, Teknologi dan Pendidikan Tinggi
Republik Indonesia
Nomor: 23/E/KPT/2019. 08 Agustus 2019
https://jurnal.umk.ac.id/index.php/kredo/index

Penelitian ini berfokus pada analisis proses morfologi pada penamaan Taman tematik di Kota Bandung berdasarkan teori O'Grandy (2016). Nama Taman tematik di Kota Bandung merupakan objek dari penelitian serta menganalisis dan mengklasifikasikan penamaan Taman kota ke dalam proses word formation.

\section{KAJIAN TEORI}

Kajian teori ini menjabarkan teori - teori yang digunakan dan menjadi dasar dalam penelitian ini yaitu morfologi, yang mana teori ini dijadikan teori utama yang akan diterapkan dalam proses penamaan pada taman tematik di kota Bandung.

\section{A. Morfologi}

Morfologi merupakan bagian dari ilmu bahasa yang memiliki banyak definisi dari berbagai aspek. Morfologi mempelajari morfem, selanjutnya ia menambahkan bahwa morfologi mempelajari dan menganalisis structure, bentuk, klasifikasi kata. Satuan terkecil yang mempunyai makna atau fungsi gramatikal disebut dengan morfem

\section{B. Morfem}

Morfem adalah bagian terkecil dari bahasa yang tidak bias dipisahkan kembali. Morfem dibagi menjadi dua yaitu free morfem dan bound morfem. Free morfem adalah morfem yang bisa berdiri sendiri, sedangkan bound morfem adalah morfem yang tidak bisa berdiri sendiri (Yule, 2010). Lebih jelasnya, berikut beberapa contoh dari bound morfem dan free morfem.

\begin{tabular}{|c|c|c|}
\hline Free Morfem & Quick & Able \\
\hline $\begin{array}{c}\text { Bound } \\
\text { Morfem }\end{array}$ & -ly & Dis- \\
\hline Words & Quickly & Disable \\
\hline Artinya & Cepat & nonaktif \\
\hline
\end{tabular}

Morfologi juga merupakan ilmu tentang pembentukan kata atau word formation termasuk bagaimana cara kata tersebut diciptakan untuk bahasa di seluruh dunia (Lieber,2009).

\section{Word Formation}

Proses pembetukan kata baru terdiri dari blending, borrowing, coined word, compounding, clipping, conversion, reduplication, acronym dan lainnya.

\section{Blending}

Blending adalah dimana mencombinasikan dua kata yang disatukan dan di produksi menjadi satu kata serta memiliki arti baru. Contoh dalam bahasa Sunda yaitu Cireng yang dimana penggabungan kata "aci" (tepung tapioka) + goreng yaitu suatu makanan yang terbuat dari tepung tapioka atau aci lalu digoreng.

\section{Borrowing}

Borrowing adalah penggunaan kata yang berasal dari bahasa lain dan digunakan dalam Bahasa Indonesia atau sebaliknya. Menurut Hatch dan Brown, 1995 dalam Rahmawati (2012) "It is all language-borrowed word from other language". Pembentukan kata borrowing biasanya diadaptasi dari phonology atau proses pengucapan bahasa yang hampir sama. Seperti kata sendal dalam Bahasa Indonesia digunakan juga kata yang serupa dalam bahasa Inggris.

\section{Coined word}

Coined word adalah proses dimana kata yang sudah ada namun dijadikan 


Kredo 4 (2020)
KREDO: Jurnal Ilmiah Bahasa dan Sastra
Terakreditasi Sinta 4 berdasarkan Keputusan Direktorat
Jenderal Penguatan Riset dan Pengembangan,
Kementerian Riset, Teknologi dan Pendidikan Tinggi
Republik Indonesia
Nomor: 23/E/KPT/2019. 08 Agustus 2019
https://jurnal.umk.ac.id/index.php/kredo/index

rujukan sebagai penamaan kata baru tanpa menggunakan proses pembentukan kata lain. Coined word didefinisikan sebuah proses dimana sebuah kata baru dibutuhkan dan dijadikan sebagai rujukan untuk bendabenda yang serupa, dan biasanya digunakan dalam pemberian nama Brand. Contohnya kata Kodak yang dijadikan sebagai Nama produk kamera, contoh lainnya "Indomie" untuk mie instan. Masyarakat selalu menggunakan kata indomie untuk menggambarkan mie instan walau dengan merk yang berbeda, sama halnya dengan "Aqua" untuk minuman kemasan.

\section{Compounding}

Compounding adalah penggabungan dua kata atau lebih menjadi kata tunggal atau bentuk baru. Pembentukan kata baru tersebut menggabungkan beberapa kategori leksikal seperti kata benda, kata sifat, preposisi, ataupun kata kerja. Contohnya dalam bahasa inggris yaitu wallpaper terbentuk dari dua kata benda wall yang artinya dinding dan paper yang artinya kertas, dan membentuk kata yang baru yaitu wallpaper.

\section{Clipping}

Clipping adalah suatu pembentukan kata yang terjadi ketika satu kata atau lebih di persingkat penyebutannya hanya satu syllable. Clipping merupakan suatu proses dimana polysyllable dirubah menjadi satu atau dua syllable yang menjadi lebih singkat. Clipping dibagi menjadi tiga type yang berbeda.

a. Foreclipping adalah bagian pertama dari kata dasar yang dihilangkan.

4 | Jurnal Kredo

Vol. 4 No. 1 Oktober 2020
Contohnya hamburger - burger.

Kata "ham" dihilangkan.

b. Backclipping adalah bagian akhir dari kata dasar yang dihilangkan. Contohnya laboratorium - lab. Kata -olaboratorium dihilangkan.

c. Fore-backclipping adalah bagian pertama dan terahir yang dihilangkan. Contohnya influenza flu. Kata awalan "in" dan akhiran "enza" dihilangkan.

\section{Conversion}

Conversion adalah perubahan fungsi dari suatu kata. Contohnya perubahan fungsi dari kata gunting (kata benda) berubah menjadi kata kerja berdasarkan kalimat, guntinglah rambutmu itu.

\section{Inflection}

Inflection adalah pembentukan kata baru yang menambahkan awalan atau akhiran tanpa mengubah kelas kata dan arti. Contohnya sebagai berikut:

a. Plural Suffixes /-s/

Book-books

b. Plural Suffixes /en/ Child-children

c. Past tense /ed/ Watch-watched

d. Comparative /er/ Tall-taller

e. Superlative /est/ Thin - thinnest

f. Continues tense /ing/ Read-reading

\section{Reduplication}

Reduplication adalah proses menduplikasi semua bagian dan kata dasar yang mana diaplikasikan dalam struktur gramatikal. Reduplication dibagi menjadi dua, yaitu full reduplication dan partial 


Kredo 4 (2020)
KREDO: Jurnal Ilmiah Bahasa dan Sastra
Terakreditasi Sinta 4 berdasarkan Keputusan Direktorat
Jenderal Penguatan Riset dan Pengembangan,
Kementerian Riset, Teknologi dan Pendidikan Tinggi
Republik Indonesia
Nomor: 23/E/KPT/2019. 08 Agustus 2019
https://jurnal.umk.ac.id/index.php/kredo/index

reduplication. Reduplication tidak semua bahasa menggunakannya, hanya beberapa bahasa saja yang menggunakan proses reduplication. Salah satunya Bahasa Indonesia dan bahasa daerah Sunda.

a. Contoh full reduplication dalam Bahasa Indonesia

Orang $=$ orang - orang

$I b u=i b u-i b u$

Bapak = bapak - bapak

b. Contoh partial reduplication dalam Bahasa Sunda.

Lumpat-lulumpatan

Ceurik-ceuceurikan

\section{Abbreviation}

Abbreviation adalah proses penghilangan sebagian dari leksem atau kombinasi leksem menjadi kata baru (Kridalaksana,2007). Abbreviation dibagi menjadi dua type yaitu:

a. Acronym adalah kata baru yang dibentuk bendasarkan inisial kata dari kata sebelumnya, dan bertujuan untuk lebih mudah di ingat dan di ucapkan contoh SMA adalah kependekan dari Sekolah Menengah Atas atau dalam bahasa Inggris $C D$ yaitu Compact Disk.

b. Initialism adalah kata yang terbentuk dari huruf awalnya saja dengan cara dibaca dieja (spelling word). Contohnya UN dari asal kata Ujian Nasional.

\section{Taman Kota}

Berdasarkan Kamus Besar Bahasa Indonesia, Taman memiliki arti kebun yang ditanami dengan bunga-bunga dan sebagainya (tempat bersenangsenang), dan kota memiliki arti daerah pemukiman yang terdiri atas bangunan rumah yang merupakan kesatuan tempat tinggal dari berbagai lapisan masyarakat. Maka bias diartikan taman kota merupakan kebun atau ruang terbuka hijau yang bertempat di daerah pemukiman dari berbagai lapisan masyarakat. Begitu juga meurut Irwan (2007) tanam kota adalah ruang terbuka hijau yang mempunyai fungsi utama untuk keindahan dan interaksi social. Maka dari itu taman kota sebagai ruang terbuka hijau memiliki fungsi yang sangat penting.

\section{E. Fungsi Taman Kota}

Taman kota memiliki beberapa fungsi yang meliputi fungsi lanskap, fungsi pelestarian lingkungan seperti menyegarkan udara yang menjadikan taman kota sebagai paru-paru kota, meningkatkan kelembaban juga sabagai habitat satwa dan terakhir fungsi estetika.

\section{METODE PENELITIAN}

Metode penelitian ini menggunakan metode kualitatif. Metode kulaitatif sebagai prosedur penelitian yang menghasilkan data deskriptif berupa kata - kata tertulis atau lisan dari orang orang dan perilaku yang diamati. Serta penelitian ini juga menggunakan metode deskriptif karena metode ini bertujuan untuk membuat suatu gambaran mengenai situasi atau kejadian dan dalam metode deskriptif, dalam praktek lapangannya penelitian ini menggunakan analisis dokumen yang mana penelitian dengan mengkaji arip dan dokumen yang telah dikumpulkan. Metode ini biasa disebut juga dengan analisis isi atau 


Kredo 4 (2020)
KREDO: Jurnal Ilmiah Bahasa dan Sastra
Terakreditasi Sinta 4 berdasarkan Keputusan Direktorat
Jenderal Penguatan Riset dan Pengembangan,
Kementerian Riset, Teknologi dan Pendidikan Tinggi
Republik Indonesia
Nomor: 23/E/KPT/2019. 08 Agustus 2019
https://jurnal.umk.ac.id/index.php/kredo/index

content analysis. Pengumpulan suatu data yang relatif terbatas dan dan tujuan pokoknya memecahkan masalah dari data yang diperoleh (Hikmat, 2011).

Sumber data penelitian di ambil dari situs web resmi di Jawa Barat, yaitu : www.seputarbandungraya.com. Dalam situs web tersebut terdapat 24 nama taman tematik yang baru dibangun atau pun rekapitulasi dari taman sebelumnya yang sudah ada. Teknik analisis data yang pertama, kumpulkan terlebih dahulu ke 24 nama taman dan di analisis berdasarkan arti nama secara harfial berdasarkan Kbbi. Kedua klasifikasikan ke 24 nama taman tersebut kedalam beberapa klasifikasi berdasarkan proses morfologisnya. Ketiga, mencari proses yang paling dominan dalam proses penamaan.

\section{HASIL DAN PEMBAHASAN}

Dari data yang telah di kumpulkan sebanyak 24 nama taman tematik di Kota Bandung, penulis menemukan empat perbedaan proses morfologi dalam penamaan taman tematik di kota Bandung yaitu: Blending, Borrowing, Coined word, dan Compounding.

\section{A. Blending}

Blending adalah dimana mengkombinasikan dua kata yang disatukan dan di produksi menjadi satu kata serta memiliki arti baru. Disini, penulis menemukan hanya satu data yang menggunakan proses blending dalam penamaan taman tematik di Kota Bandung.
(Data 1: Taman Lansia)

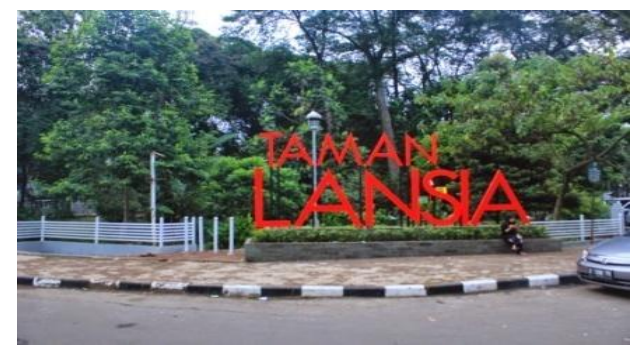

(https://www.17sekians.com/refreshing-saatsore-hari-di-taman-lansia-bandung/)

Taman lansia adalah taman yang dimana terletak di jalan Cisangkuy Bandung. Taman ini sering digunakan untuk olahraga atau sekedar rekreasi dengan keluarga. Kata "lansia" merupakan sebuah proses morfologi dimana mengkombinasikan kata menjadi satu, yaitu blending names. Kata "Lanjut" dan "Usia" dikombinasikan maka terbentuklah kata "lansia" yang artinya orang yang sudah tua (lanjut usia). Taman ini tidak hanya diperuntukan untuk orang yang sudah lanjut usia, namun bisa untuk semua kalangan.

\section{B. Borrowing}

Borrowing adalah penggunaan kata yang berasal dari bahasa lain dan digunakan dalam Bahasa Indonesia atau sebaliknya. Penamaan taman tematik ini terdapat 10 taman yang menggunakan proses borrowing. Berikut data nama taman berserta analisisnya. 


Kredo 4 (2020)
KREDO: Jurnal Ilmiah Bahasa dan Sastra
Terakreditasi Sinta 4 berdasarkan Keputusan Direktorat
Jenderal Penguatan Riset dan Pengembangan,
Kementerian Riset, Teknologi dan Pendidikan Tinggi
Republik Indonesia
Nomor: 23/E/KPT/2019. 08 Agustus 2019
https://jurnal.umk.ac.id/index.php/kredo/index

(Data 2: Taman Vanda)

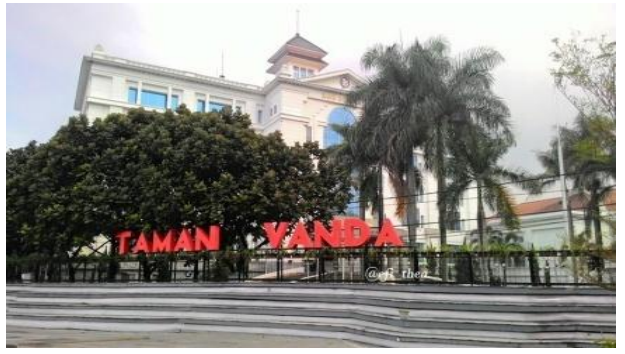

(https://www.google.com/search?q=taman+va $n d a \& t b m=i s c h \& v e d=2 a h U K E w j D 2 r v 43 v n r A h$ XMGnIKHeU9Aw8Q2-

cCegQIABAA\#imgrc $=$ erMatBX8fR4J5M)

Taman Vanda di kota Bandung terletak di Jalan Merdeka bawah. Seperti taman - taman lainnya, taman Vanda juga sering digunakan masyarakat untuk rekreasi atau sekedar meluangkan waktu senggang dan biasa digunakan oleh anak muda. Nama Vanda berasal dari bahasa Sanksekerta yang artinya indah. Dan nama Vanda di ambil dari sebuah nama bunga yaitu bunga Anggrek yang sangat indah sesuai dengan arti dari nama Vanda tersebut. Disini terlihat penggunakaan nama mengambil dari bahasa selain bahasa Indonesia, bisa dikatan bahwa proses borrowing digunakan dalam penamaan taman tersebut.

(Data 3: Taman Jomblo)

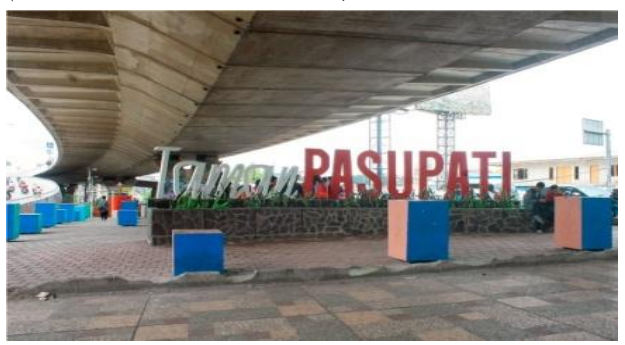

(https://tourbandung.id/taman-pasupati/)

Taman Pasupati adalah salah satu taman yang digemari oleh kaum muda. Taman ini terkenal dengan taman jomblo karena konsep dari taman ini adalah pemerintah kota Bandung membuat sebuah konsep dimana terdapat beberapa tembok - tembok berfungsi untuk tempat duduk. Taman Jomblo ini terletak di bawah jalan layang pasupati dan bersampingan dengan taman film dan taman skateboard. Kata jomblo berasal dari bahasa Sunda yaitu "Jomlo" yang artinya gadis tua. Kata jomblo memberi makna sendiri atau orang yang masih sendiri (belum menikah) seperi tembok - tembok yang sengaja dibuat untuk orang yang datang sendiri. Namun itu hanya istilah saja. Warga Bandung dan sekitarnya boleh mengunjungi taman tersebut bersama sama. Ini menunjukan proses borrowing terjadi dilihat dari penamaan taman yang menggunakan bahasa lain selain bahasa Indonesia.

(Data 4: Taman Musik)

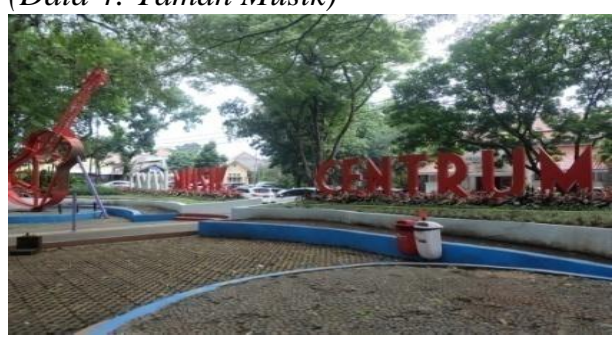

(https://byanjauharsaladin.blogspot.com/2019/ 08/musik-located-in-sumbawa-streetnumber.html)

Taman musik yang bertempat di jalan Belitung, Sumurbandung, kota Bandung. Taman ini awalnya bernama Taman Centrum. Namun, sekrang berubah menjadi taman musi. Taman tersebut biasa digunakan untuk anak anak band yang gemar bermusik. Kata musik awalnya dari bahasa Yunani yaitu "Mousike" yang mana digunakan untuk sebutan nama dewi perempuan Zeus. Serta dalam bahasa Latin yaitu 


Kredo 4 (2020)
KREDO: Jurnal Ilmiah Bahasa dan Sastra
Terakreditasi Sinta 4 berdasarkan Keputusan Direktorat
Jenderal Penguatan Riset dan Pengembangan,
Kementerian Riset, Teknologi dan Pendidikan Tinggi
Republik Indonesia
Nomor: 23/E/KPT/2019. 08 Agustus 2019
https://jurnal.umk.ac.id/index.php/kredo/index

"Musica" yang memiliki arti sebuah pengekspresian dalam kehidupan manusia. Maka bisa terlihat bahwa kata "musik" merupakan kata yang masuk kedalam proses morfologi yaitu borrowing word.

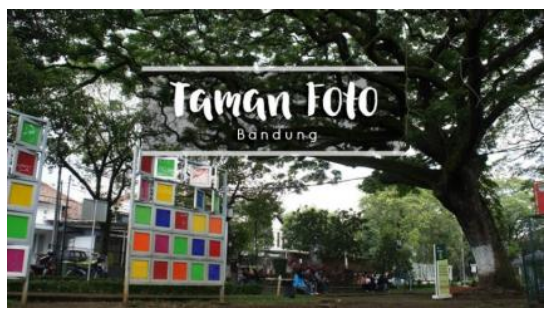

(Data 5: Taman Fotografi)

(https://reisha.net/blog/wp-

content/uploads/2018/01/taman-foto-bandung800x445.jpg)

Tanam Fotografi yang awalnya bernama taman Cempaka merupakan taman di ruang terbuka dan dibuka untuk umum. Taman tersebut berada di jalan Anggrek, kota Bandung. Kata Fotografi berasal dari negara Yunani yaitu "Photos" yang artinya cahaya dan juga "Grafo" yang artinya melukis, maka Photografi yaitu media menulis atau melukis menggunakan cahaya. Kata Fotografi bisa dikatakan masuk kedalam proses morfologi yaitu borrowing word yang dimana kata tersebut bukan asli dari bahasa Indonesia.

(Data 6: Taman Film)

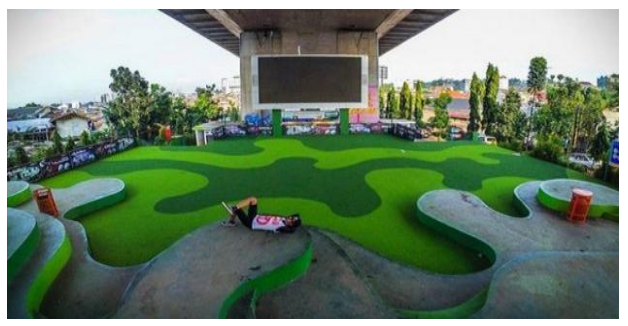

(https://www.jejakpiknik.com/wpcontent/uploads/2019/06/tamanfilmbandungO630x380.jpg)

8 | Jurnal Kredo

Vol. 4 No. 1 Oktober 2020
Taman Film merupakan taman yang dibangun khusus warga untuk menonton film. Taman tersebut terletak dibawah jalan layang Pasupati. Kata "Film" diambil dari arti yang sebenarnya yang berasal dari Bahasa Inggris yaitu gambit hidup. Proses yang dilakukan dalam penamaan taman ini adalah proses borrowing yang mana asal katanya dari Bahasa Inggris.

(Data 7: Taman Pet Park)

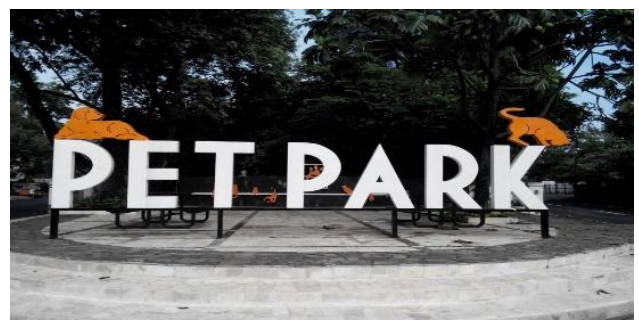

(https://iO.wp.com/cakrawalatour.com/wpcontent/uploads/2020/02/25-pet-park-afandi640x480-1-200x135.jpg)

Taman Pet Park ini berada di jalan cilaki. Taman ini dijadikan untuk masyarakat uang khususnya hobi memelihara hewan peliharaan. Tempat ini dijadikan tempat berkumpulnya para pecinta hewan peliharaan. Proses yang digunakan dalam penamaan taman tersebut menggunakan proses borrowing yang mana asal kata pet park diambil dari Bahasa Inggris.

\section{(Data 8: Super Hero)}

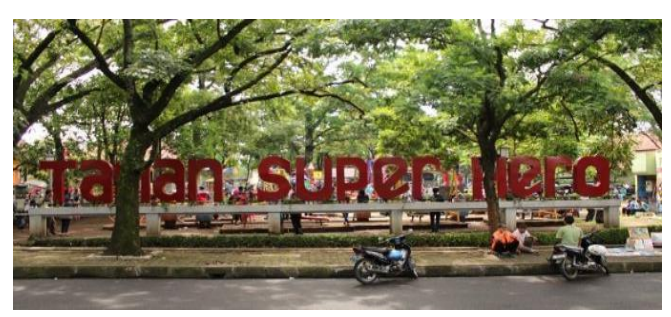

Taman Superhero ini terletak di jalan Bengawan Bandung. Disana 


Kredo 4 (2020)
KREDO: Jurnal Ilmiah Bahasa dan Sastra
Terakreditasi Sinta 4 berdasarkan Keputusan Direktorat
Jenderal Penguatan Riset dan Pengembangan,
Kementerian Riset, Teknologi dan Pendidikan Tinggi
Republik Indonesia
Nomor: 23/E/KPT/2019. 08 Agustus 2019
https://jurnal.umk.ac.id/index.php/kredo/index

terdapat beberapa patung superhero terkenal dan juga ada salah satu superhero local yaitu Gatotkaca. Kata Superhero disini diambil dari bahasa Inggris yang menggandung arti pahlwan super. Maka dari itu terlihat proses yang digunakan dalam penamaan taman yaitu proses borrowing.

(Data 9: Taman Skateboard)

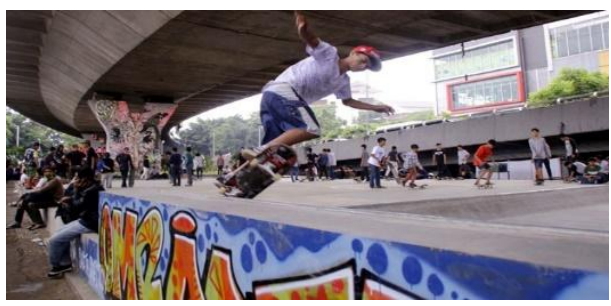

(https://www.destinasibandung.co.id/wpcontent/uploads/2015/06/statik.tempo_.co_.jpg )

Taman Skateboard terletak di bawah jalan layang Pasupati dan berdekatan dengan dua taman sebelumnya yaitu Taman Jomblo dan Taman Film. Taman ini didesign khusu untuk anak muda dan masyarakat lainnya yang suka dengan olahraga Skateboard. Kata Skateboard memiliki arti papan luncur. Kata tersebut juga diambil dari Bahasa Inggris yang sekaligus menjelaskan bahwa penamaan taman ini menggunakan proses borrowing.

(Data 10: Cikapundung Riverspot)

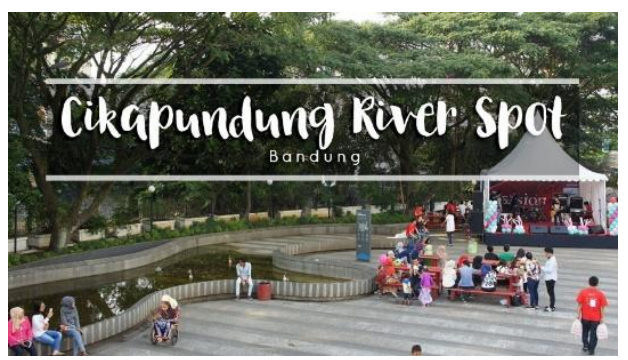

(https://reisha.net/blog/wpcontent/uploads/2018/01/cikapundung-riverspot-.jpg)

Cikapundung Riverspot yang terletak di jalan Dr. Ir. Sukarno. Suasana taman ini mengadaptasi dari penataan ruang public di Cannes, Perancis. Dalam data ini, penulis mengambil objek yang akan diteliti adalah dari kata "River spot". River spot diambil dari bahasa Inggris yang memiliki arti secara literal adalah titik sungai. Maka, river spot ini merupakan titik sungai cikapundung tersebut. Pemilihan nama "River spot" yang diambil dalam bahasa Inggris, itu menunjukan bahwa proses penamaan menggunakan proses borrowing.

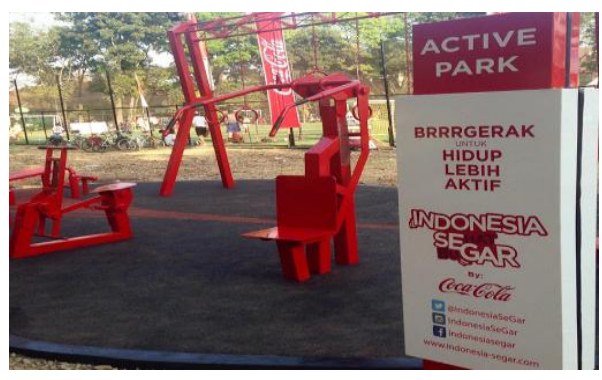

(Data 11 : Active Park)

(https://lh3.googleusercontent.com/proxy/pjiB wDOw-

lCLZmqb9rWY9kwKsk1Yv1vvWcNhMlLP-

d_7aweiYQw3zltuEaJztp1AwPXdL6ZHvJ4Dt9 rkSGITp_VIKiUPMI-

pjndcRJ1oKJQz5sJuq30Fj1mP70l6huNO7w)

Active park merupakan salah satu taman yang menghadirkan program pemerintah untuk meningkatkan kesehatan masyarakat. Taman ini berada di kawasan taman supratman. Dilihat dari namanya "active park", taman yang satu ini terlihat jelas menggunakan bahasa Inggris yang artinya aktif. Disini menunjukan 


Kredo 4 (2020)
KREDO: Jurnal Ilmiah Bahasa dan Sastra
Terakreditasi Sinta 4 berdasarkan Keputusan Direktorat
Jenderal Penguatan Riset dan Pengembangan,
Kementerian Riset, Teknologi dan Pendidikan Tinggi
Republik Indonesia
Nomor: 23/E/KPT/2019. 08 Agustus 2019
https://jurnal.umk.ac.id/index.php/kredo/index

bahwa proses pembentukan kata baru dalam penamaan taman active park yaitu menggunakan proses borrowing.

\section{Coined}

Coined word didefinisikan sebuah proses dimana sebuah kata baru dibutuhkan dan dijadikan sebagai rujukan untuk benda- benda yang serupa, dan biasanya digunakan dalam pemberian nama Brand. Disini, proses coined word terlihat pada penggunaan nama taman yang mengambil dari nama - nama yang sudah ada. Dalam proses coined word, terdapat 7 data nama taman. Berikut analisis datanya.

(Data 12: Taman Dewi Sartika)

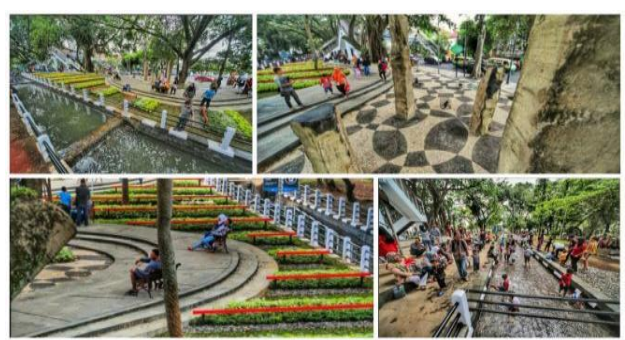

(https://thumb.viva.co.id/media/frontend/thumb s3/2015/12/02/198776-0_665_374.jpg)

Taman Dewi Sartika bertempat di kawasan Balai Kota yang dahulu bernama Taman Merdeka. Namun, pada tahun 1996 Pemkot Bandung mengganti dengan nama Taman Dewi Sartika. Nama Dewi Sartika adalah nama dari seorang pahlawan nasional wanita kelahiran Bandung, beliau seorang penggagas pendidikan untuk kaum wanita. Nama Dewi Sartika dalam penamaan taman ini bisa diklasifikasikan kedalam Coined word karena Dewi Sartika adalah sebuah nama yang di ambil dari nama Pahlawan Nasional.

(Data 13: Taman Pramuka)

10 | Jurnal Kredo Vol. 4 No. 1 Oktober 2020

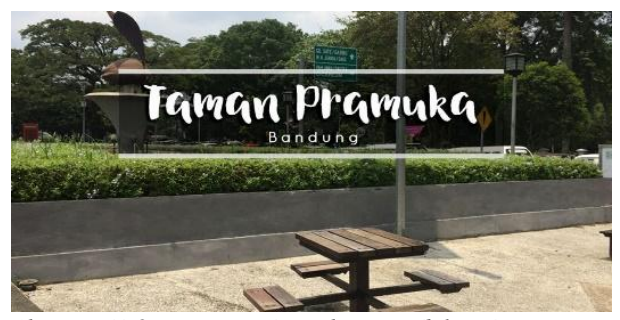

(https://iO.wp.com/reisha.net/blog/wpcontent/uploads/2018/01/taman-

pramuka.jpg $?$ fit $=900 \% 2 C 600 \&$ quality $=98 \&$ st rip $=$ all \&ssl $=1 \&$ resize $=346 \% 2$ C188)

Taman Pramuka yang terletak di jalan Riau Bandung ini merupakan area tempat wisata kuliner di kota Bandung. taman ini biasanya digunakan untuk berkumoulnya para anggota pramuka dan menjadi tempat tongkrongan anak muda. Kata "Pramuka" menurut Kamus Beasr Bahasa Indonesia adalah organisasi untuk pemuda yang mendidik para anggotanya dalam keterampilan, disiplin, kepercayaan pada diri sendiri, saling menolong dan sebagainya. Taman pramuka disini mengandung arti yang sama dengan pengertian pramuka yang sebenarnya. Maka dari itu, proses penamaan taman pramuka ini menggunakan proses coined word.

(Data 14: Taman Inklusi)

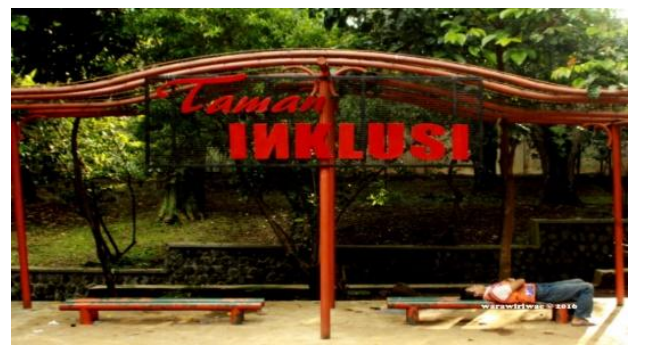

(https://warawiriwae.files.wordpress.com/2016 /04/img_1297-001.jpg?w=788\&h=527)

Taman Inklusi merupakan taman yang diperuntukan untuk masyarakat 


Kredo 4 (2020)
KREDO: Jurnal Ilmiah Bahasa dan Sastra
Terakreditasi Sinta 4 berdasarkan Keputusan Direktorat
Jenderal Penguatan Riset dan Pengembangan,
Kementerian Riset, Teknologi dan Pendidikan Tinggi
Republik Indonesia
Nomor: 23/E/KPT/2019. 08 Agustus 2019
https://jurnal.umk.ac.id/index.php/kredo/index

yang memiliki keterbatasan (disabilitas) tapi banyak juga masyarakat lainnya yang berkunjung dan menhabiskan waktunya disana. Taman ini didesign khusus agar kaum disabilitas bisa nyaman dan aman menggunakan semua fasilitas taman. Taman ini terletak di jalan Aceh Jalan Saparua Bandung. Sama halnya dengan Taman Paramuka, Taman Inklusi ini juga termasuk kedalam proses coined word karena berdasarkan arti dari Kamus Besar Bahasa Indonesia, Inklusi adalah kegiatan mengajar siswa dengan kebutuhan khusus.

\section{(Data 15 : Taman Pers)}

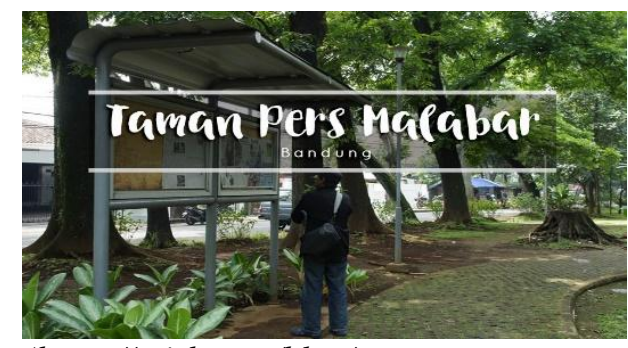

(https://reisha.net/blog/wp-

content/uploads/2018/01/taman-pers-

malabar.jpg)

Pemerintah kota Bandung mendesign khusus taman ini untuk teman - teman pers. Tempat ini bertujuan sebagai salah satu tempat berkumpulnya para wartawan, tempat berdiskusi, maupun tempat memberikan berita. Taman pers ini bertempat di jalan Malabar dekat dengan pasar kosambi, Bandung. menurut Kamus Besar Bahasa Indonesia, kata Pers memiliki arti yaitu media penyiaran berita, seperti surat kabar, majalah, radio, televisi dan film. Bersadarkan arti pers menurut KBBI dan deskripsi mengenai taman pers disini memiliki kesamaan arti. Maka dari itu proses morfologi dari nama taman pers disini menggunakan proses coined word.

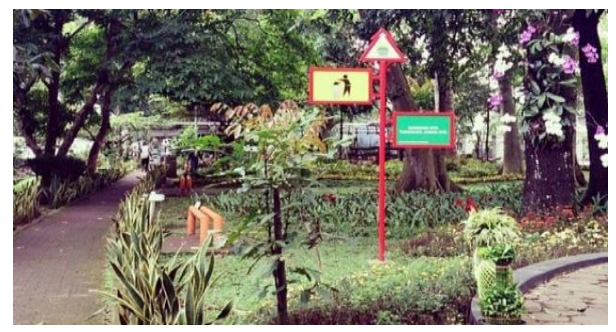

(Data 16: Taman Pustaka Bunga Cilaki) (https://www.jejakpiknik.com/wpcontent/uploads/2019/06/tamanpustakabunga8 -630x380.jpg)

Pemerintah Kota Bandung saat ini banyak merevitalisasikan taman taman dahulu yang kurang diminati masyarakat menjadi taman yang menjadi objek utama wisata masyarakat, salah satunya adlah taman pustaka bunga cilaki ini. Taman ini bertempat di jalan cilaki Bandung. berdasarkan Kamus Besar Bahasa Indonesia, kata "pustaka" memiliki arti antara lain kitab, buku, primbon atau kumpulan bahan - bahan rujukan. Arti dari KBBI mengenai kata "pustaka" ini sama tujuannya dengan proses penamaan taman pustaka bunga cilaki oleh pemerintah kota Bandung yang ining menjadikan taman ini perpustakaan atau rujukan. Hal ini betujuan bagi masyarakat yang ingin mengetahui berbagai jenis bunga yang ditanam, bisa mengunjungi taman tersebut. Maka dari itu, proses penamaan ini menggunakan proses coined word karena tema dari 


Kredo 4 (2020)
KREDO: Jurnal Ilmiah Bahasa dan Sastra
Terakreditasi Sinta 4 berdasarkan Keputusan Direktorat
Jenderal Penguatan Riset dan Pengembangan,
Kementerian Riset, Teknologi dan Pendidikan Tinggi
Republik Indonesia
Nomor: 23/E/KPT/2019. 08 Agustus 2019
https://jurnal.umk.ac.id/index.php/kredo/index

pemberian nama taman dan arti secara harfiah memiliki kesamaan.

(Data 17: Taman Lalu Lintas)

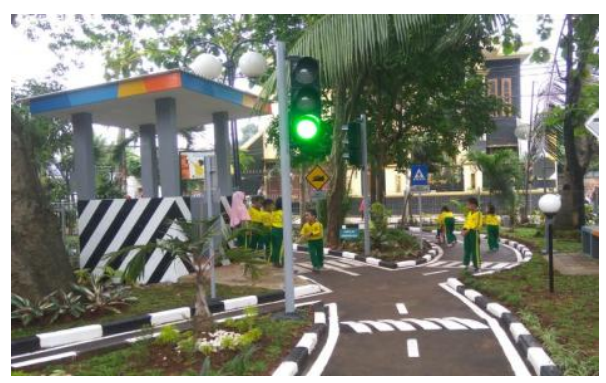

(https://asset.kompas.com/crops/nAOLr_mtgn MD4p5rzSYM33mNesw=/0x19:851x586/490x 326/data/photo/2018/02/22/3955660053.jpeg)

Taman lalu lintas atau Taman Lalu Lintas Ade Irma Suryani Nasution berada di jalan Belitung, Sumur Bandung, Kota Bandung. Taman ini merupakan tempat rekreasi bagi anak anak dikarenakan banyak miniature kendaraan terdapat disana, serta banyak juga berbagai jenis tanama Bunga maupun jenis pohon yang ditanam di taman tersebut. Proses morfologi pada penamaan taman ini termasuk kedalam proses coined word. Itu semua dikarenakan adanya nama anak salah satu pejuang Indonesia. Ade Irma Suryani Nasution adalah anak bungsu dari Jenderal Besar Dr. Abdul Harris Nasution.

(Data 18: Taman Gesit)

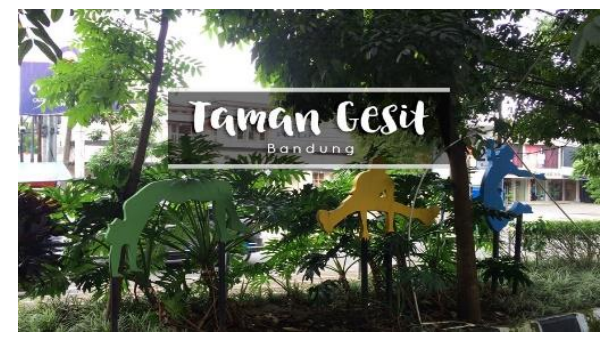

12 | Jurnal Kredo Vol. 4 No. 1 Oktober 2020 (https://reisha.net/blog/wpcontent/uploads/2018/11/taman-gesit1280x720.jpg)

Tanggal 1 April 2015 yang lalu, Pemerintah Kota Bandung meresmikan Taman Gesit. Taman Gesit ini terletak dijalan Dipatiukur, Lebakgede, Kecamatan Coblong, Kota Bandung. pemerintah membuat taman ini bertujuan untuk masyarakat khususnya warga Bandung agar hidup lebih sehat dan gesit. Taman Gesit ini berada di ruang terbuka hijau. Kata "Gesit" diambil dari Bahsa Indonesia, yang mana menurut Kamus Bsesar Bahasa Indonesia, kata "Gesit" artinya cekatan. Maka, proses penamaan taman ini termasuk kedalam proses coined word yang artinya proses dimana kata yang sudah ada namun dijadikan rujukan sebagai penamaan kata baru tanpa menggunakan proses pembentukan kata lain

\section{Compounding}

Proses yang terakhir adalah proses morfologi pada data compounding yang akan di jelaskan di bawah ini.

\section{Data 19: Cibeunying Park)}

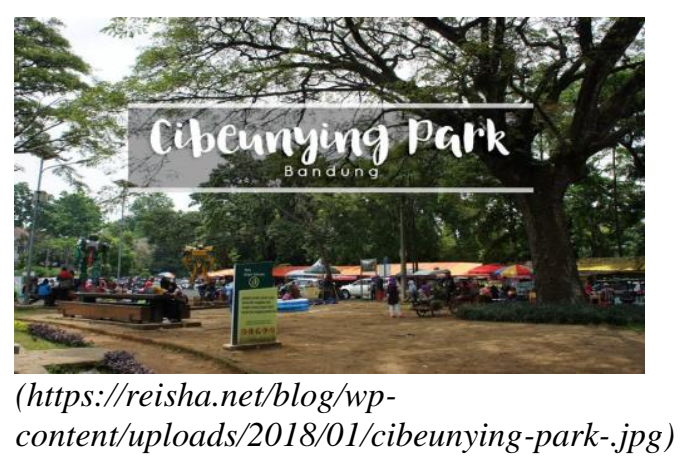

Cibeunying Park adalah tempat destinasi dikota Bandung Barat. 


Kredo 4 (2020)
KREDO: Jurnal Ilmiah Bahasa dan Sastra
Terakreditasi Sinta 4 berdasarkan Keputusan Direktorat
Jenderal Penguatan Riset dan Pengembangan,
Kementerian Riset, Teknologi dan Pendidikan Tinggi
Republik Indonesia
Nomor: 23/E/KPT/2019. 08 Agustus 2019
https://jurnal.umk.ac.id/index.php/kredo/index

Tempat ini berada di jalan cibeunying, Kota Bandung. Cibeunying Park menampilkan beberapa hiasan seperti robot - robot yang bertujuan meningkatkan minat kunjung masyarakat untuk berkungjung kesana. Proses penamaan taman ini menggunakan proses compounding. Kata Cibeunying diambil dari dua kata yaitu "Ci" yang arti dalam bahasa Sunda adalah air dan "beunying" merupakan nama sebuah tanaman yang nama latinnya adalah Ficus fistulosa yang umumnya dikenal dalam bahasa sunda adalah tanaman Beunying. Arti kata Cibeunying adalah air dari tanaman Beunying.

(Data 20 \& 21: Taman Teras Cikapundung dan Cikapundung Riverspot)

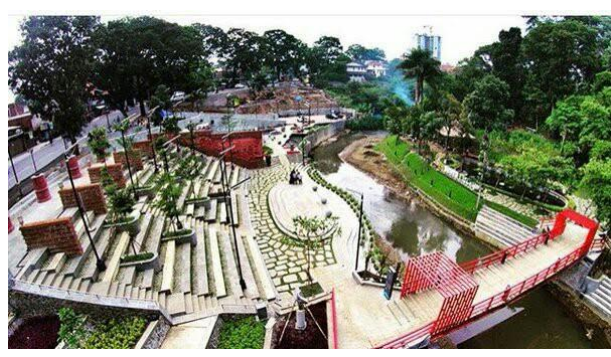

(https://1.bp.blogspot.com/t1USP3dD02Q/WmDOKOJYwOI/AAAAAAAA BmE/nOa7oc68_oUTSx-6H38mR3tTD1wiLUiwCLcBGAs/s1600/amphitheater-TerasCikapundung-BBWS-Bandung.jpg)

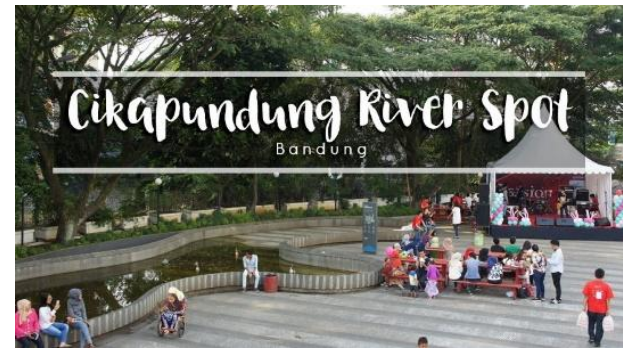

(https://reisha.net/blog/wpcontent/uploads/2018/01/cikapundung-riverspot-.jpg)
Taman Teras Cikapundung yang berada di jalan Siliwangi Bandung merupakan taman yang cocok untuk pengunjung untuk bersantai atau berfoto. Konsep dari taman ini yaitu berkonsep urban dan ekologi yang berada di ruang public. Selain taman Teras Cikapundung, ada juga Cikapundung Riverspot yang terletak di jalan Dr. Ir. Sukarno. Suasana taman ini mengadaptasi dari penataan ruang public di Cannes, Perancis. Terlepas dari nyaman dan terkenalnya kedua taman dengan nama yang hampir sama ini, penulis terpaku pada kata "Cikapundung" yang berasal dari bahasa Sunda. Kata "ci" yang berartikan cai atau air, sedangkan "kapundung" merupakan nama sebuah tanaman yaitu tanaman kepundung (Beccaurea SPP). Dilihat dari analisis nama taman tersebut, bias dikatakan bahwa kedua taman tersebut menggunakan proses pembentukan kata baru yang disebut dengan compounding.

\section{(Data 22: Taman Cikapayang Dago)}

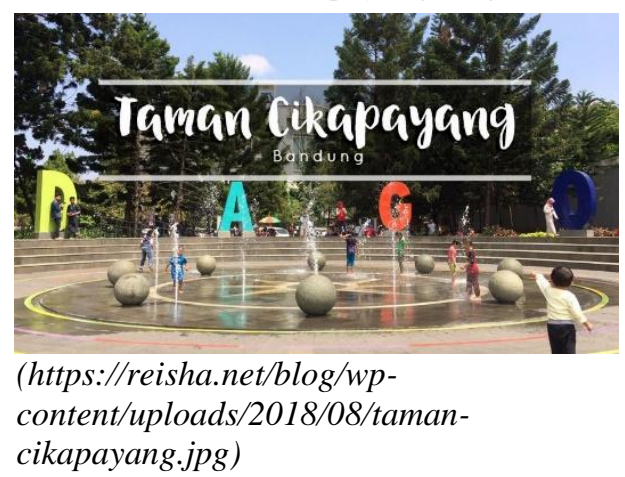

Taman Cikapayang Dago terletak di Jalan Ir. H. Djuanda no 79, Lebak Siliwangi, Bandung. Taman ini 


Kredo 4 (2020)
KREDO: Jurnal Ilmiah Bahasa dan Sastra
Terakreditasi Sinta 4 berdasarkan Keputusan Direktorat
Jenderal Penguatan Riset dan Pengembangan,
Kementerian Riset, Teknologi dan Pendidikan Tinggi
Republik Indonesia
Nomor: 23/E/KPT/2019. 08 Agustus 2019
https://jurnal.umk.ac.id/index.php/kredo/index

berlokasi strategis di kawasan pusat wisata Dago Bandung. Sama halnya dengan Teras Cikapundung dan Cikapundung Riverspot, Taman Cikapayang ini merupakan proses compounding dari kata "ci" dan "Kapayang". Kata "ci" yang artinya cai atau air, sedangkan "Kapayang" merupakan nama dari sebuh tanaman.

(Data 23: Taman Tegallega)

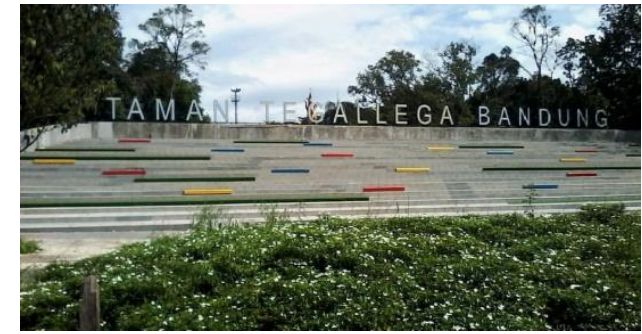

(https://tourbandung.id/wp-

content/uploads/2019/05/Taman-Tegalega1030x541.jpg)

Taman Tegallega berada di sebrang museum Sri Baduga. Tman ini merupakan taman luas kira - kira 16 hektare. Terlepas dari sejarah taman ini, nama Tegalega terdiri dari dua suku kata yaitu tegal dan lega. Menurut Kamus Besar Bahasa Indonesia, kata “ tegal" memiliki arti tanah yang luas serta rata ( yang ditanami palawija dan sebagainya dengan tidak menggunakan system irigasi dan bergantung pada hujan) dan kata "lega" berasal dari Bahasa Sunda yaitu luas. Maka kata tegallega memiliki arti secara harfiah yaitu tanah atau lading yang luas. Sama dengan sejarah yang menyebutkan taman tegallega Dago memiliki luas tanah yang besar. Dari kedua kata tersebut membuktikan bahwa adanya proses pembentukan kata baru yaitu compounding dari kata "Tegal" dan "Lega".

14 | Jurnal Kredo Vol. 4 No. 1 Oktober 2020
(Data 24: Alun - Alun Ujung Berung)

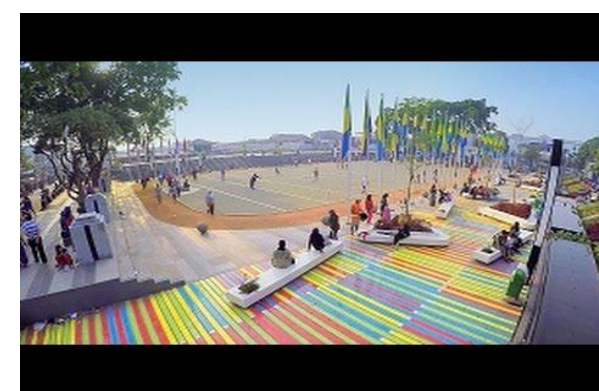

(https://i.ytimg.com/vi/MDkxBU87WSs/hqdefa ult.jpg)

Alun - alun ujung berung terletak di jalan ujung berung, Bandung Timur. Alun - alun ini disamping masjid Agung Ujung berung. Asal mula dari kata ujung berung yaitu dahulu rombongan dipati ukur dikejar oleh tentara mataram, sampai di sebuah kota yang mana dipati ukur dikepung oleh tentara mataram namun tidak diketemukan, pada saat itu merupakan peristiwa berakhirnya proses pengepungan yang cukup panjang. Ujung berung terdiri dari dua suku kata yaitu kata "ujung" yang arti dalam Bahasa Sunda yaitu akhir, dan "Berung" artinya nafsu atau mengumbar nafsu. Ini menjelaskan bahwa penggabungan dua kata menjadi satu arti yang baru yaitu proses compounding.

\section{SIMPULAN}

Dari hasil penelitian mengenai proses penaman taman temantik di kota Bandung ini dapat disimpulkan bahwa dari kesembilan proses pembetukan kata baru (word formation), hanya terdapat empat proses yang digunakan dalam 


Kredo 4 (2020)
KREDO: Jurnal Ilmiah Bahasa dan Sastra
Terakreditasi Sinta 4 berdasarkan Keputusan Direktorat
Jenderal Penguatan Riset dan Pengembangan,
Kementerian Riset, Teknologi dan Pendidikan Tinggi
Republik Indonesia
Nomor: 23/E/KPT/2019. 08 Agustus 2019
https://jurnal.umk.ac.id/index.php/kredo/index

penamaan taman kota Banding. Diantaranya yaitu 1) blending word yaitu proses mencombinasikan dua kata yang disatukan dan di produksi menjadi satu kata serta memiliki arti baru. 2) Borrowing word adalah proses penggunaan kata yang berasal dari bahasa lain dan digunakan dalam Bahasa Indonesia atau sebaliknya. 3) Coined Word adalah proses dimana kata yang sudah ada namun dijadikan rujukan sebagai penamaan kata baru tanpa menggunakan proses pembentukan kata lain. Dan yang terakhir adalah Compunding. Compounding adalah penggabungan dua kata atau lebih menjadi kata tunggal atau bentuk baru.
Pembentukan kata baru tersebut menggabungkan beberapa kategori leksikal seperti kata benda, kata sifat, preposisi, ataupun kata kerja.

Proses morfologi yang dominan digunakan dalam penamaan taman di Kota Bandung adalah Borrowing word. Dari data yang telah dianalisis berikut nama taman yang menggunakan proses borrowing yaitu Taman Vanda, Taman Fotografi, Taman Jomblo, Taman Film, Taman Musik, Taman Skateboard, Taman Superhero, Active Park, Pet Park, dan Cikapundung River Spot. Penggunaan bahasa Inggris lebih mendominasi pada proses borrowing dibandingan dengan bahasa lainnya.

\section{DAFTAR PUSTAKA}

Hikmat, D. M. 2011. Metode Penelitian Dalam Perspektif Ilmu Komunikasi dan Sastra. Yogyakarta: Graha Ilmu.

Irwan, Z. D. 2007. Prinsip - Prinsip Ekologi: Ekosistem Lingukngan dan Pelestarian. Jakarta: Bumi Aksara.

Kasiahe, E. M., Pamantung, R. P., \& Kalangi, L. M. 2019. Proses Morfologis Pada Pembentukan Nama-nama Marga Etnis Sangihe. NUSA, 169 - 183.

KBBI, 2020.https://kbbi.kemdikbud.go.id/

Kridalaksana, H. 2007. Pembentukan Kata dalam Bahasa Indonesial Harimurti Kridalaksana. Jakarta: Gramedia Pustaka Utama.

Lieber, R. 2009. Intoducing Morphology. New York: Cambridge University Press.

O'Grandy, W. 2016. Contemporary lInguistics Analysis: An Introduction Eight Edition. Canada: Pearson Canada Inc.

Rahmawati, A. 2012. Word Formation Processes on Slang Words used by Transsexual. Semarang: Universitas Diponegoro. 


Kredo 4 (2020)
KREDO: Jurnal Ilmiah Bahasa dan Sastra
Terakreditasi Sinta 4 berdasarkan Keputusan Direktorat
Jenderal Penguatan Riset dan Pengembangan,
Kementerian Riset, Teknologi dan Pendidikan Tinggi
Republik Indonesia
Nomor: 23/E/KPT/2019. 08 Agustus 2019
https://jurnal.umk.ac.id/index.php/kredo/index

Rahma, N. I. 2020. Relasi Sematik Pada Penamaan Jenis - Jenis Mangga Di Indonesia. Jurnal KREDO, 322 - 337.

Santosa, M. P. 2020. Analisi Penamaan Kedai Kopi Di Surabaya: Kajian Etnolinguistik. Jurnal KREDO, 386 - 399.

Sujatna, E. T., Heriyanto, \& Pamungkas, K. 2016. Morphological Processes of Jawa Barat Tourism Destination Naming. INTCESS2016 3rd International Conference on Education and Sosial Sciences, (pp. 158 - 162). Bandung.

Yule, G. 2010. The Study of Language, Fourth Edition. New York: Cambridge University Press. 